\title{
THE ROYAL ALBERT HOSPITAL: THE MIDDLE YEARS
}

\author{
Joe Alston, Administrator 1938-78
}

The first patients were admitted to the hospital in December 1870 , and were selected in proportion to the amount of money subscribed by each county, as follows:

$\begin{array}{lcc}\text { County } & \text { Patients } & \text { Amount contributed (£) } \\ \text { Lancashire } & 20 & 31,824 \\ \text { Yorkshire } & 12 & 15,731 \\ \text { Durham } & 5 & 1,915 \\ \text { Westmorland } & 4 & 2,306 \\ \text { Cumberland } & 3 & 975 \\ \text { Cheshire } & 3 & 982 \\ \text { Northumberland } & 3 & 703\end{array}$

Two patients were discharged during the first year, one because his friends could no longer pay his fees and the other because of severe epilepsy. By 1871 there were 66 patients, including the first from Lincolnshire, and the committee made it known that whilst there was room, paying patients would be accepted from any area. The report of the Commissioners in Lunacy, who first inspected the hospital in 1871, tells us that "the Asylum is not intended for Epileptic, Paralytic or Insane persons" and that the fees start at "fifty guineas per annum and rise by increments of 50, to 200 guineas. The children of persons in narrow circumstances, who cannot afford the full payment of 50 guineas, are receivable at 20 guineas per annum." Visiting was allowed on the first and third Thursday of each month and anyone could go to the asylum on Mondays, if recommended by a subscriber.

\section{LIFE FOR THE PATIENTS}

One of the principal functions of the asylum was, wherever possible, the education and training of the patients. Mrs Mills, wife of the chief attendant, was responsible for the boys' education, and a master organised physical training for them. Some boys also did simple industrial work, some worked in the gardens or helped to look after the pigs and poultry, and others helped in the different domestic departments. The first girls were admitted as patients in 1871 and by 1873 the medical superintendant's report stated that "All patients whose state of health permits attend school each day for periods proportioned to their respective capacities. Thus 34 of the lowest grade of intellect are instructed in the classroom daily for half an hour only; 38 others more intelligent but of tender years, form an infant class which meets each morning for one hour; a mixed school of about 80 selected boys and girls pleasantly spend the first hour of the afternoon in conjoined singing and kindergarten exercises; and for another hour and a half 34 girls receive, in their own classroom, instructions both in matters of ordinary scholastic routine and in industrial employments suitable to their sex... Increasingly useful work is done by the boys and girls: the former work as shoemakers, tailors, joiners, basketmakers, farm boys, garden boys, boot cleaners, laundry boys, corridor cleaners, [and] some are also employed as errand boys. The latter work as bedmakers, kitchen assistants, scrubbing, scullery, [and] wardrobe. (14 girls do needlework in school and 4 do plain knitting)." By 1875 this had expanded to include matmaking, coir twisting and hair picking.

An article in the Manchester Examiner and Times in 1875 reports on a patient who worked in the matmaking department and "whose case is remarkable as illustrating mental and moral improvement in a short space of time. The lad is now familiarly known in the Asylum by the name of Diogenes, because, before his admission, and for some time afterwards, he actually lived in a tub. He entered only a year ago at the age of fourteen. His behaviour was then almost maniacal, and it was at first a matter of doubt whether he could be allowed to remain. Diogenes kicked, and swore, and spat, and would not be pacified until his tub was restored to him. In the tub he sat with his deformed legs and toes coiled under him, observing what went on around him from a sort of bunghole. In this extraordinary manner he had been kept out of mischief at home, and to restore to him his dwelling was now the only means of reconciling him to the Asylum. By kind treatment the character of the lad has been surprisingly altered for the better. He has now abandoned the tub, and expresses some contempt for it. His limbs are improving, though he will always be a cripple, and his disposition has been softened and his good qualities elicited in no unsatisfactory measure . . The civilisation of this poor lad, and the well-grounded hope that he may go back to the world some day, a useful and well-behaved man, instead of a trouble and source of anxiety and mischief to all around him, speak volumes for the work of the Royal Albert Asylum. The case of Diogenes shows that the moral sense is carefully cultivated in the Asylum."

Whereas this article praises progress of patients at the Asylum and indeed the progress of Diogenes, it is reported that later this boy developed suicidal tendencies and had to be transferred to a lunatic asylum. Other extracts from the Medical Superintendant's reports of the 1870 s detail the progress of other patients:

"Girl aged 9, admitted two years ago. Physically a wellformed child, but owing to irritation of the brain, very restless, and had rubbed hair off the back of her head. Educational attainments - nil. Now, a well-conducted, interested-looking child, without any symptoms of nervous irritation. Is making good progress with reading, writing, and adding. Can hem and knit and make beds, and is always pleased to make herself useful to her companions." 
There are also letters from the families of patients expressing their pleasure at the changes they see in the children:

"I think my son has greatly improved, and he is much more intelligent and helpful than when he entered the Royal Albert Asylum. His health is very good, and he seems to be improving in every way. Great praise is due to the way in which the patient is treated in the Royal Albert Asylum."

"I find my daughter's memory and intellect a good deal improved since she entered the Royal Albert Asylum, and she has been very useful in domestic work while at home . . I think she has greatly improved during the last twelve months."

In 1898 the principal's report quoted a letter written by a young basket-maker who was nearly blind and almost totally deaf:

\section{"My dear Father and Mother,}

I was very much pleased to get a letter from you and to hear you had started work again. You must be very careful and not meet with another accident. I hope your arm will soon be better again.

I am very well. And I am getting on with the BasketMaking. Mr Diggens says I have to be the best basket-maker in the Asylum. I hope I shall.

I should be sorry to take a shilling [5p] off you, you have no call to send it. I have got 5/7 [28p], I am saving up to 10/[50p] to get another watch. If you want the money I have I shall send it to you, you must let me know soon. I would not like to come home this year but shall be glad to see you next year.

Could I get any basket-making about Newcastle. I would be glad to get there and help you.
Will you kindly let me know in your next letter.

I shall be very pleased to see you again and see how you are getting on.

I remain

Your loving Son.”

The writer Hesba Stretton, in a piece published in the Sunday Magazine in January 1885 gives an idea of how institutions such as the Royal Albert were viewed:

"... It is not yet fourteen years since the Asylum was opened today, in May 1884, there are 516 inmates gathered within its sheltering walls. The primary object of the place is to make it a school for the educating of the dormant faculties of imbecile children; they are admitted between the ages of six and fifteen, for a term of seven years. It is not a life refuge - there are only five life cases in the Asylum, all the others are children sent to school, either by election or by the payment of charges varying with the requirements and the circumstances of the friends who sent them . . Five hundred and sixteen of nature's failures of human fragments! These are the lowest of all in the innumerable ranks of mankind... . a cloud will always hang about them, the darkness can never quite pass away. . . each of them represents a home made anxious or wretched by their presence in it, unless they can return to it, after seven years' training, with some power of making themselves useful . . The boys on the farm were fine strong young fellows, who seem to be able to gain their own living if they could find places under patient and considerate masters who would not take advantage of their halfwittedness. One of the great wants of the institution is this kindly cooperation of employers, who would take an interest in the recovered or improved imbecile after he leaves the Asylum. A little patience, a little indulgence, pity and charity might save many of them from falling back into the depth from which they have been rescued.'

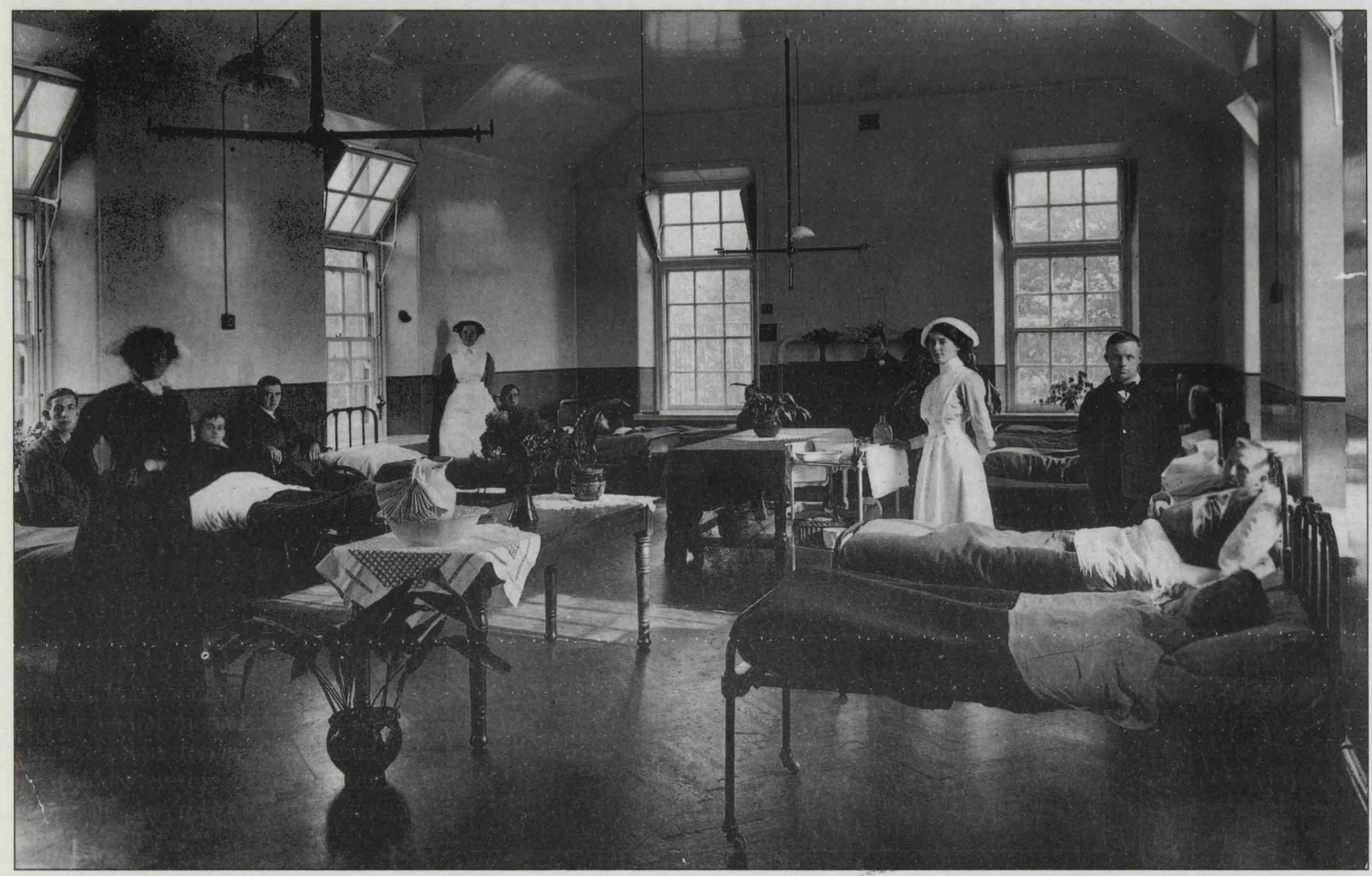

Infirmary Ward, 1916 
The piece from which this extract is taken was titled "One of God's Palaces".

\section{Rodgett Infirmary}

Following a severe epidemic of scarlatina in 1877 the necessity for a detached infirmary was considered. This had been repeatedly recommended by the Commissioners in Lunacy who in their report of April 1878 stated that the outbreak of scarletina showed "the great necessity in an Institution of this size and character, of a detached hospital", and in their 1880 report they hoped "that the Committee will be able with little delay to provide this most necessary adjunct". The erection of such an infirmary was so strongly urged by the medical members of the Central Committee and by the medical staff of the Royal Albert that the committee instructed the architects of the asylum, Paley and Austin of Lancaster, to prepare suitable plans. A special appeal for contributions followed, and $\mathrm{Mr}$ and Mrs Rodgett of Preston donated $£ 5,000$, and the infirmary opened in 1882 .

\section{Brunton House}

Three years later the chance arose to buy two large houses with some land, which lay a short distance from the asylum. Their purchase cost $£ 3,600$ and the buildings were modified for use as a boarding house for special private patients. This was reported at the annual general meeting of 1885: the purchase ". . . was deemed advisable in view of the inevitable growth and extension of the Institution . . . The establishment will be under the same medical and general administration as the Asylum, with which it will have telephonic communication. It will happily combine the advantages and comforts of a private home with the various sources of instruction, occupation and amusement, and the responsible management of a large public institution. Though the wealthy may be able at home to surround their imbecile children with every comfort and kindness, they cannot there obtain such science, skill and sources of amusement and occupation as a well-managed institution affords. As there had been several inquiries for this kind of accommodation and such singularly convenient property being in the market, the Committee decided, after careful deliberation, not to miss the opportunity of acquiring it. In grateful recognition of the munificence of the late Mr James Brunton, who contributed the original donation to establish the Royal Albert Asylum, it has been decided to call the property 'Brunton House'.'

Burnton House was closed and sold in 1936. The building, which is on Greaves Road opposite the Methodist Church, has since been divided into flats.

\section{Working conditions for the staff}

In 1907 the working conditions for the staff were as follows:

\section{Hours of duty (male and female)}

Monday to Saturday, 6.30am to $7 \mathrm{pm}$, one early evening finishing at $5.30 \mathrm{pm}$. No-one allowed out on Saturdays, every other Sunday off. One day off each month, to be taken or kept to count as annual leave.

\section{Wages}

Female $£ 15$ a year, male $£ 30$ a year.

\section{Clothing (female)}

Three dresses, twelve pinafores, four net caps provided annually. Print dresses were worn for daily work for which six yards of grey striped material were issued for each of two dresses; black cashmere dresses were for Sunday wear, for which six yards of material were issued. Dresses were made up in the Sewing Room.

\section{Clothing (male)}

Uniform was issued: one suit (dog collar style) and one pair of working trousers

\section{Meals for resident staff}

Breakfast: bread and butter (find own preserves)

Lunch: supplied from kitchen and served in Servants' Hall (females) and Mess Room (male).

Tea: bread and butter (seed bun on Tuesday, currant bun on Friday, cheese on Friday)

Supper: bread and butter

Rations issued: A quarter pound of tea and $1 \mathrm{lb}$ of sugar per week. Half pound of butter each Monday, a quarter pound of butter on Friday. One pint of milk per day.

\section{Discipline}

Strict discipline was enforced. Male and female staff were not allowed to communicate. Many a passing of the sexes in the corridors resulted in winks or pulled faces, but to be caught was a crime. A nurse, having taken her early evening the night before, was called to Matron's office to explain what she was doing on the front drive waving to an attendant in the Male Mess Room. Her answer that it could not possibly have been so, for at the hour in question she was in the Skerton district was met with Matron's rebuff, "Enough of this, nurse, don't let it occur again", and she was dismissed from the room.

A male attendant was called to the office of the Chief Attendant to explain his behaviour in that he passed the Medical Superintendent on the main corridor and did not salute him. The attendant stated that the Medical Superintendant seemed deep in thought, head down, chin almost on chest, and could not possibly have seen him, but he or someone had, and this resulted in a stern rebuke from the Chief Attendant.

No make-up or jewellery was allowed on duty, nor was walking out of the grounds when coming off duty.

Married men were allowed to live out only every other night, and had to obtain permission to be on 'married staff'.

Despite all the discipline, the long hours, the petty restrictions, and the low pay, I am informed that there was an extremely happy atmosphere, and there seemed to be no lack of entertainment. Strange to say, the strict segregation of the sexes did not prevent many romances, starting from a wink or a face-pull, blossoming into marriage. The success of applicants for posts was governed by their talents, preference being given to musicians, singers and sportsmen who played football and cricket. This was to provide entertainment for the patients. Many concerts were given, again necessitating long working hours for the staff.

In 1908, with the sanction of the committee, it was arranged that the male staff slept in rooms apart from the patients, a favour which was greatly appreciated.

In 1910 the institution was incorporated under the title 'The Royal Albert Institution, Lancaster'.

There seems to have been remarkably little change in the routines at the Royal Albert over some years. My parents were both employed there during the first decade of the 
century, and I began work there in 1938: apart from salaries, all other aspects of life there were very much the same. I was part of a self-supporting establishment, a community akin to a reasonably-sized village with its own farm of 280 acres, with livestock, pigs, poultry and large vegetable production, which supplied the needs of the staff and patients, with potatoes for all but six or eight weeks of the year and fresh vegetables in abundance. The farm had its own slaughterhouse where the hospital butcher slaughtered weekly but could not meet the demand. There was a daily supply of 120 gallons of milk, and each day the bakehouse supplied $250 \times 3^{1} \frac{1}{2} \mathrm{lb}(1600 \mathrm{gm})$ loaves - six days white, one day brown. Meals were wholesome and probably as good if not better than those in some of the poorer homes.

Male and female patients were allocated tasks, for which they were not paid (this being a ruling in the staff conditions of contract). Many male patients worked making baskets, mats, mattresses, toys and brushes; some did shoe-cleaning, some worked in the stores, in the butcher's shop, bakehouse, boiler house, laundry, workshops, book bindery or print works, on the farm or in the gardens. Female patients worked in the kitchens, laundry, schools, workrooms and mending rooms, did the household chores on the female wing and produced knitted work, which, like the men's handiwork, was collected and taken to towns holding a general annual meeting, where it was sold. As many as seven large hampers accompanied the delegates going to such meetings.

Strict discipline was in force and the segregation of the sexes persisted. Communicating doors or gates between the female and male wings were locked at all times and no patient entered unless under staff supervision. Clothing was 'institution style' and made in the tailors' shop - 250 suits a year, and numerous pairs of cotton tweed trousers for incontinent patients. The female clothing was also made on site: grandrille dresses for work and regatta print dresses for out of working hours. Before linen items or clothing were replaced, they had to be assessed by Matron and the Steward, who would judge and recommend, and before some things were finally considered unfit for further use they were patched and patched again to the point where the original material was almost nonexistent. Sheets were cut and sewn from linen sheeting bought on the roll, and pillow cases from pillow cotton on the roll. Towels were also made: crash for roller towels, huckaback for hand towels, twill calico for bath towels and terry towelling for the officers' towels. Table cloths were made from art serge or damask, and napkins from damask.

Ward walls were pine boarding to dado level, and cream paint above. Each ward had six or eight chairs round a table in the middle of the room, as well as seating along the walls, and a huge fireplace.

The patients were confined to the grounds and playing fields area, or were sometimes taken out locally in groups of up to 50 for supervised walks.

\section{SUMMARY}

It can be seen that there was little change in conditions for patients or staff during the period 1900-1945. I know of no written evidence from the earlier years.

The hospital has sought and been granted royal patronage from five monarchs. Up until 1934 seven further buildings including the infirmary block were added, and in 1945 came a most significant and beneficial change, when the Rushcliffe Report recommendations on wages and conditions of service were adopted. This brought the staff at the Royal Albert into line with staff in county-financed establishments. Huge changes were on the horizon in the 1940s, with the voluntary era of care giving way to the new National Health Service. The third and concluding article in this series will cover from the late 1940 s to the present day.

\section{Acknowledgment}

Much of the source material for this article was used in the volume 'The Royal Albert, Chronicles of an Era', published by CNWRS in 1992. Enquiries should be directed to $\mathrm{Dr} E$ Roberts, Centre for North-West Regional Studies at Lancaster University, Bailrigg, Lancaster. 